\title{
Salami tactics and the implementation of large-scale public projects
}

Markus Hinterleitner

KPM Center for Public Management, University of Bern, Switzerland

Journal of European Public Policy, https://doi.org/10.1080/13501763.2018.1544654.

\begin{abstract}
This article builds on the literature on policy failure and blame management to analyse the implementation of large-scale public projects, which frequently suffer from cost overruns and delays. The article addresses a hitherto neglected blame management strategy used by politicians overseeing implementation: the stepwise announcement of delays and/or cost overruns, often referred to as 'salami tactics'. I assert that politicians apply salami tactics in order to reduce and deflect the blame for a project that turns out to be more expensive, or takes longer to complete, than initially communicated. The empirical section examines the use of salami tactics in two large-scale public projects that resulted in delays and cost overruns: the Berlin Brandenburg Airport in Germany and the Swiss National Exposition Expo.02. Both cases confirm my arguments regarding the blame-reducing and blame-deflecting effects of salami tactics and reveal that this strategy can cause projects to lock-in on a self-undermining path.
\end{abstract}

\section{Keywords}

Blame avoidance, blame management, framing contests, policy failure, policy implementation, public projects 


\section{Introduction}

Research shows that blame management adopted by reputation-sensitive politicians has implications for the trajectory of public policies (e.g. Boin et al. 2009; Weaver 1986; McConnell 2017). This article contributes to this literature by examining political blame management during the implementation of large-scale public projects. Transport infrastructure, public buildings, IT and defence projects often end up being more expensive than expected, take longer to complete or are less beneficial to society than projected (Flyvbjerg et al. 2003; van Marrewijk et al. 2008). I focus on two aspects of large-scale public projects which, to date, have not received enough attention in the literature: the politics that surround the implementation of large-scale public projects and, in particular, the strategies that politicians apply in order to defend overoptimistic projects during implementation.

Drawing on concepts from the literature on blame avoidance and blame management (Weaver 1986; Hood 2011; Hinterleitner 2017), I provide the first systematic account of a widely observed, but hitherto neglected, behavioural phenomenon among politicians responsible for large-scale public projects: the stepwise announcement of delays and/or cost overruns, frequently referred to by political opponents and the media as ‘salami tactics’ (e.g. Flyvbjerg et al. 2002, 281). ${ }^{1}$ By communicating delays or cost overruns in stages during the implementation phase, instead of comprehensively assessing and communicating them as soon as possible, politicians partition blame into smaller, more easily manageable, parts. Moreover, politicians can more credibly shift responsibility for delays or cost overruns onto project contractors if the announced delays or cost overruns do not appear to be too severe. Salami tactics are highly consequential for the fate of individual projects and for the allocation of public resources. By delaying the revelation of a project's real benefit-cost ratio (BCR), salami tactics prevent

\footnotetext{
${ }^{1}$ I thank Tobias Arnold for pointing me to this phenomenon.
} 
adaptations and readjustments in the early stages of the implementation phase that could save public resources.

This article proceeds as follows. After providing a short overview of the various drivers of overoptimistic forecasts, I conceptualise the implementation phase of an overoptimistic public project as a political 'framing contest' about the public perception of that project (Boin et al. 2009). In the course of this framing contest, the politician(s) responsible for the project must engage in blame management in order to save the project from becoming a perceived policy failure. I then claim that using salami tactics is a strategy that serves this purpose. The empirical section examines the application of salami tactics during the implementation of two large-scale public projects that experienced significant delays and cost overruns: the Berlin Brandenburg Airport in Germany and the Swiss National Exposition Expo.02. The analysis confirms that in both cases, politicians applied salami tactics in order to manage the blame that emerged when it became clear that the respective projects could not be completed on time and within the budget. The cases further reveal that salami tactics prolong the resolution of underlying problems and can lead to significant extra costs and delays. After discussing the findings from the cases, I recommend that in future research scholars combine the study of policy failures with the blame management perspective in order to further elucidate the implementation of large-scale public policy projects.

\section{The role of salami tactics in the framing contests of overoptimistic projects}

Large-scale public projects often end up being more expensive than expected, take longer to complete or are less beneficial to society than projected. The literature discusses a number of reasons why large-scale public projects are frequently based on overoptimistic forecasts (Jennings 2012; Sanderson 2012; Flyvbjerg et al. 2003). Technical explanations attribute forecasting errors to the complexities and uncertainties inherent in every large-scale project. 
During implementation, complex projects often encounter difficulties that the original BCR did not consider.

Psychological explanations apply concepts of bounded rationality, such as the 'optimism bias', to explain overoptimistic forecasts (Lovallo and Kahneman 2003). The literature suggests that project planners and politicians in charge of a planned project frequently develop overoptimistic beliefs about the positive aspects and the feasibility of the project and are therefore susceptible to communicating 'inflated’ BCRs to the public.

Finally, political explanations attribute overoptimistic forecasts to ‘strategic misrepresentation’ on the part of prospective project contractors and politicians. Given the high level of contestability of information during the project planning phase, the actors involved have the opportunity to present this information according to their interests. Namely, project contractors deliberately propose overoptimistic forecasts on costs, benefits and conversion times because doing so serves their economic self-interest. If these project contractors present their proposals favourably, their chance of acceptance rises. Political actors, such as state governments, departments or individual politicians are considered to be eager to accept the overoptimistic project estimates presented by contractors since they increase the public acceptance of the project and increase the likelihood of project approval (Flyvbjerg et al. 2002). Although scholars are continuously debating the relative causal weight of the drivers of overoptimistic forecasts (Jennings 2012; van Marrewijk et al. 2008), they widely consider political explanations to be an important driver.

An overoptimistic or 'inflated' BCR unavoidably diminishes during the implementation of the project when it becomes clear that the project cannot be completed as promised. In the course of this process, the project begins to appear in a less favourable light. If the BCR diminishes, more and more parties will begin to argue that maintaining the project is not worth paying an additional price, that it cannot be waited for any longer, or that it can no longer be considered as a success given that the promised benefits will not materialise. As a result, a political 
'framing contest' begins. During such a contest, political actors and the media struggle to anchor an updated perception of the project in the public's mind that takes into account the diminished BCR (Boin et al. 2009). The dominant public perception that results from the framing contest can be expected to fall within ‘a spectrum from success to failure’ (McConnell 2011, 71), i.e. from a still favourable perception of the project to a very negative perception of it as an outright fiasco or disaster. Conceptualising the implementation phase of overoptimistic projects as a framing contest acknowledges that not only the decision-making phase leading up to their adoption is a political process, their implementation is as well.

Public projects based on overoptimistic forecasts are a problem for the politician(s) overseeing the implementation of these projects. In the course of the framing contest about an overoptimistic project, the politician(s) responsible receive(s) blame from political opponents, the media and the public. Political opponents are especially likely to attempt to exploit delayed or over expensive public projects and to use them as 'blaming opportunities' (Boin et al. 2009). They can accuse the politicians in charge of having accepted an overoptimistic forecast in the first place (if they were already in office at the time of project approval), of not having intervened earlier or of not being honest to the public about the 'real' BCR of the project. The politicians in charge of overseeing implementation are very likely to perceive such accusations as a threat to their reputation (Hinterleitner and Sager 2018). This is especially true when a delayed or costly project turns into a 'focusing event', with political opponents successfully portraying it as a policy fiasco or disaster, in which accusations and blame often become uncontrollable and dangerous for the politicians in charge (Birkland 1998; Hood et al. 2009; Bovens and 't Hart 1996). To limit their negative effects, politicians must engage in the framing contest about the public project and take measures to prevent it from being perceived as a clear instance of policy failure.

How can this be done? Blame attacks consist of two elements: They combine an emphasis on loss or harm with an assignment of responsibility for that loss or harm (Hood 2011). Hence, in 
order to fend off the blame attacks from political opponents and the media, politicians must address both elements. They must decrease the perceived salience of announced delays or cost overruns and deflect the perceived responsibility for delays or cost overruns onto other actors involved in the implementation of the project (Hinterleitner and Sager 2017). I assert that the deliberate stepwise announcement of delays and/or cost overruns, frequently referred to as ‘salami tactics’ (Flyvbjerg et al. 2002, 281), addresses both elements of blame attacks. First, if delays or cost overruns are communicated in stages, the perceived loss at any one time is smaller. For instance, an announced delay of one year weighs less than an announced delay of three years. Smaller losses appear less salient to the public and thus attract less blame from the media and from political opponents (Pal and Weaver 2003). Consequently, salami tactics make it easier for politicians to still eventually portray a delayed or over expensive project as an overall policy success. I thus expect that:

E1: The use of salami tactics decreases the perceived losses associated with a project whose BCR is diminishing.

Second, smaller delays or cost overruns should not only attract less blame, they should also be easier to blame on project contractors and to be portrayed as cases of misinformation. The more serious the delays or cost overruns, the less credible it is for the politician to claim that he was misled and was unaware about the misrepresentation in the first place. If cost overruns and delays are significant, it is much less likely that political opponents and the media will believe the blame-shifting move of the politician. Instead, they will inquire as to why the politician was prepared to believe an utterly unrealistic forecast in the first place. Hence, I expect that:

E2: The use of salami tactics decreases the perceived responsibility of (a) politician(s) for a project whose BCR is diminishing.

Taken together, I perceive salami tactics as a blame management strategy in the tug-of-war over the public perception of a project. Salami tactics facilitate the management of the blame that 
emerges as a project's BCR diminishes and helps to ward off reputational damage by keeping the project in the 'success zone' of perceived policy outcomes (Bovens and 't Hart 2016; McConnell 2010). Figure 1 summarises my conceptualisation of the implementation phase of overoptimistic projects, as well as the role of salami tactics in saving the project from becoming a perceived policy fiasco during this phase.

Figure 1. The role of salami tactics during the implementation of overoptimistic projects

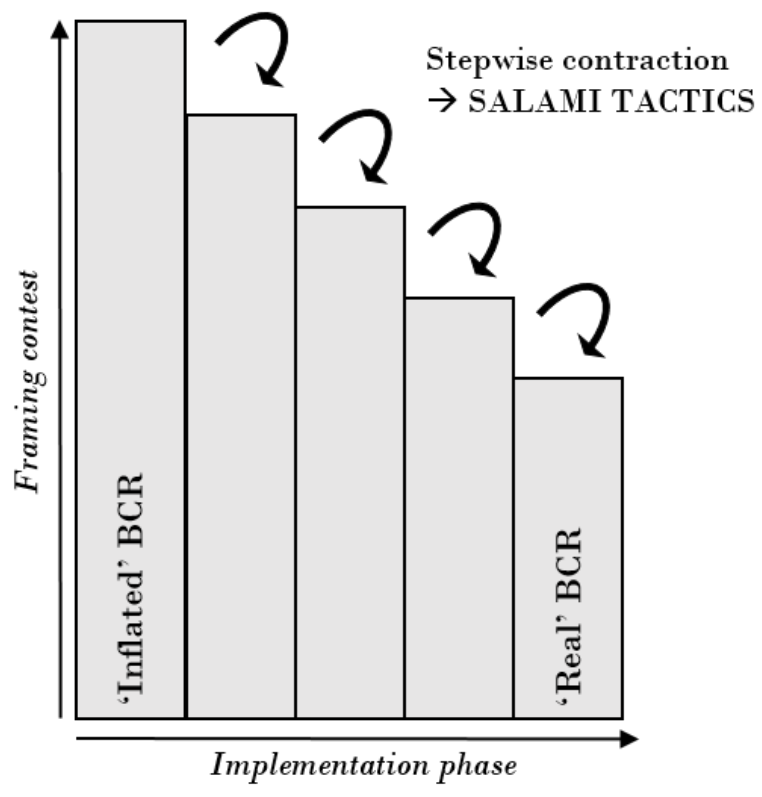

\section{Research design}

In the following section, I test the blame-reducing and blame-deflecting effects of the use of salami tactics and explore their consequences on the implementation of two large-scale public projects that experienced significant delays and cost overruns. The Berlin Brandenburg Airport (BER) in Germany and the Swiss National Exposition Expo.02 were selected based on two case selection criteria, which together provide "the kind of control and variation required by the research problem” (George and Bennett 2005, 83; for a similar research design, see Weaver 2014). First, both cases were verifiably based on BCRs that were already overoptimistic at the 
time of project approval. This is not a precondition for the use of salami tactics, as politicians can also use these tactics to address technical problems that inadvertently arise during implementation. However, the more optimism that is built into an initial forecast, the more blame will emerge during the implementation phase and, accordingly, the greater the need for blame management. This makes the cases suitable for exploring the use of salami tactics and testing their blame-reducing and blame-deflecting effects. Second, the two cases are very different in terms of project type and political contexts, and they reveal two different variants of salami tactics. The logic of the 'most different' case design serves two purposes. First, the differences between the cases can be leveraged to create additional insights on the concrete shape, applicability and consequences of salami tactics. Second, uncovering evidence for salami tactics in two very different cases increases the likelihood that they are indeed a widespread behavioural phenomenon that occur during the implementation of public projects. Table A1 in the Online Appendix provides a systematic overview of the case selection criteria and their purposes in light of the present analysis.

When examining the use of salami tactics, the empirical challenge is to show that stepwise announcements are actually made by a politician who announces opening dates or cost estimates that deliberately go against his better judgement. After all, stepwise announcements can also be made by a politician who announces opening dates or cost estimates to the best of his knowledge. To empirically differentiate between these alternative explanations for stepwise announcements, I specifically focus on the level of information that the politician responsible for the project possesses when he announces a delay or cost overrun. If I can demonstrate that the politician possessed specific information, but withheld or deliberately ignored it when announcing an opening date or cost estimate, I interpret it as a form of salami tactics.

Since it is often difficult to provide strong evidence that unequivocally confirms the use of salami tactics (on this see below), the analysis combines evidence drawn from a vast volume of qualitative data: transcripts of parliamentary debates, media coverage of both cases, official 
reports by inquiry commissions and expert reports. Table A2 in the Online Appendix provides an overview of the main data and their primary uses. I systematically coded data with NVivo 11, which allows for the extraction of information from large quantities of text and its allocation to several research-specific 'nodes'. First, I coded the public statements of the politicians in charge and those of their political opponents. This allowed me to assess whether politicians made step-wise announcements during the implementation of the project, how they justified them and how political opponents reacted to them. Examining both the justifications of the politicians in charge and the reactions of their political opponents allowed me to test the blamereducing and blame-deflecting effects of step-wise announcements. Second, I extracted information from official reports to gauge the level of information that the politicians in charge possessed when announcing cost overruns or delays.

Following a short case description, I first demonstrate that the project was adopted based on an overoptimistic project forecast. I then show that stepwise announcements were the result of salami tactics and not just a consequence of developments unforeseen by the politician. Subsequently, I test the expectations formulated in the theory section about the blame-reducing and blame-deflecting effects of salami tactics. The final analytical step proceeds in an explorative manner to assess whether salami tactics affect cost development, completion time and the coming to terms with underlying problems.

\section{Salami tactics during the construction of the Berlin Brandenburg Airport in}

\section{Germany}

Following German reunification, political discussions began regarding the creation of a modern hub airport in the former eastern German territory. Proponents of the new airport expected it to replace the three small existing airports of Tempelhof, Tegel and Schönefeld. Berlin and the State of Brandenburg, in cooperation with the federal government, decided to build the new 
hub at the site of the former Schönefeld airport close to the city of Berlin. After a failed attempt in 1999 to tender the project concession to a private contractor, the three shareholders decided to build the airport under the aegis of a public holding. When construction began in September 2006, estimated costs were quoted at 2.1 billion Euros, with the airport scheduled to open in October 2011.

In June 2010, the Mayor of Berlin, who was also the chairman of the board of the public holding (the politician responsible for the implementation of the project), surprised the public by announcing that the opening of the airport would be postponed from October 2011 to June 2012. He justified this decision by citing the unanticipated bankruptcy of a construction planning company and the stricter safety requirements mandated by the European Union, which had to be incorporated into the construction process. The delay, communicated in June 2010, was the first of a total of five postponements that the mayor announced from 2010 until 2014, when growing political pressure and blame forced him to resign. At the time of writing (September 2018), the scheduled airport opening date is 2020, at the earliest, with costs expecting to exceed 7 billion Euros by its completion. From 2010 to 2014, political opponents often criticised the mayor for standing by an announced opening date even after compliance with that date had become factually impossible and for too readily announcing the next optimistic opening date. This behaviour nurtured the suspicion that the mayor made these precipitant announcements in order to assuage public outrage.

\section{An inflated BCR}

In this case, the mayor not only endorsed an overly optimistic project forecast, but he also actively reached out for one. When the three shareholders first attempted to tender the project in 1999, they only received offers that were far too costly to ensure the swift approval of the project by the parliaments and populations of the two notoriously cash-strapped German federal states. They therefore announced that they would build the airport 'cheaper and better' than any private contractor could (Hoffmann 2012). Experts widely agree that the project plan that the 
public holding used to begin building the airport was far too optimistic in several regards. Capacity estimates were set at the lowest possible level in order to downplay the problem of fly-over noise in the surrounding areas (Hoffmann 2012). Investment in noise control measures, an unavoidable expense for an airport built so close to the city centre, were estimated at an unrealistically low level (Fülling 2014). In sum, the mayor revealed a clear preference for an overoptimistic project forecast instead of obtaining estimates that were as accurate as possible, thereby laying the groundwork for an implementation phase in which the inflated BCR unavoidably had to diminish.

\section{The use of salami tactics}

There is considerable evidence that the mayor hastily announced a new opening date when he faced blame for an unmet one, without being able to base the new opening date on reliable information. This pattern is particularly visible in May 2012, when the June 2012 opening was cancelled at short notice. The opposition and media subsequently blamed the mayor for not having communicated the second postponement earlier. In response, he claimed that the management had not adequately informed him about the further delay. The ensuing court ruling (Berlin Regional Court 2014) reveals that the mayor must have known about the problems that led to the second postponement before May 2012 and thus could not have been surprised by this outcome. It also shows that the mayor announced the new estimated opening date of March 2013, which he announced immediately after a board meeting in May 2012, against better judgement. Shortly before this board meeting, the executing companies informed the mayor that they were unable to guarantee a binding opening date unless they could solve some crucial construction process problems (Berlin Regional Court 2014). Despite these significant restrictions, the new estimated opening date was set for March 2013, and the mayor, when publicly expressing his confidence in the new opening date, made no mention of the considerable uncertainties related to this date (Berlin House of Representatives [BHoR] 2012a, 1002-1007, 2012b). 
Just how unfounded the March 2013 date was became clear four months later when the mayor announced the third postponement, this time from March 2013 to September 2013. Following the announcement of the second postponement, the board had replaced the chief planner in charge of coordinating the implementation phase. When parliament forced the mayor to justify the third delay, he announced that only then, after a four month settling-in period of the new chief planner, did the board possess an accurate overview of the situation and could thus confidently announce September 2013 as a new 'realistic' opening date (BHoR 2012d, 15531554). This statement indirectly reveals that back in May 2012, the mayor did not have enough reliable information at his disposal to realistically announce the March 2013 date. In sum, there is considerable evidence that the mayor did not announce opening dates to the best of his knowledge but rather applied salami tactics in order to prevent the project from turning into a perceived policy fiasco.

\section{The blame-reducing and blame-deflecting effects of salami tactics}

The use of salami tactics helped the mayor to reduce the blame that emerged when the overoptimistic BCR of the planned airport was diminishing. The announcement of an opening date in the very near future allowed the mayor to continue to frame the whole airport project as an overall policy success, from which the region would greatly benefit after completion (e.g. BHoR 2012a, 1005). As the mayor repeatedly stated, short delays of only a few months should not be used by an obstructive opposition to tarnish the overall success of the project. It is immediately obvious that the credibility of such justifications depends on a delay that does not weigh too heavily on the overall impression of a successful project. Even after this strategy lost effectiveness during later postponements, short delay announcements still allowed the mayor to make morale-boosting statements that it would not be long before the airport would open and become a huge success (e.g. BHoR 2012d, 1553).

Second, the application of salami tactics also allowed the mayor to more credibly deflect blame onto other actors involved in the construction of the airport. Each delay was justified by a 
specific (usually technical) problem, ranging from the bankruptcy of a planning company, to stricter EU safety requirements, to an inoperable fire protection system. By tying every postponement to a specific, unforeseen problem, the mayor was able, for quite some time, to

shift attention away from the underlying fact that the airport project had always been based on an unrealistic project plan. During later rounds of the protracted framing contest, the mayor repeatedly deflected blame to the management of the holding (e.g. BHoR 2013, 2249). The success of the mayor's blame management efforts can be read from the blaming patterns of political opponents. During the early phase of the implementation, opponents primarily directed their blaming efforts at the management of the holding and not at the mayor (e.g. BHoR 2012e). This only changed in August 2012, when rumours about a third delay put the mayor under increasing pressure (BHoR 2012c). Overall, there is considerable evidence that salami tactics helped the mayor to downplay perceived losses and to decrease his perceived responsibility for the delays for quite some time.

\section{Project consequences}

The consequences for the implementation of the airport project that emanated from salami tactics become obvious when we consider the costly acceleration efforts that companies adopted to somehow meet the newly announced, overambitious opening dates. To make up for previous ‘delays', companies often worked overtime and added extra shifts. Work stages, originally planned to be handled sequentially, began to be executed concurrently, increasing the planning effort and the likelihood of costly mistakes (Kurpjuweit and Tretbar 2014; Berlin Regional Court 2014). Moreover, the recurrent firing of managers in response to unmet opening dates also led to the loss of know-how during the implementation phase. At the political level, the use of salami tactics long prohibited a thorough examination of the manifold problems at the root of the original project proposal. By continuously suggesting that the opening of the airport was within reach, the mayor kept the perceived loss tolerable for too long. 


\section{Salami tactics during the preparation of the Swiss National Exposition}

\section{Expo.02}

In the 1990s, a political discussion began about holding a new national exposition in Switzerland. After several cantons and cities submitted their applications, Switzerland's collective executive government, the Federal Council (FC; the political actor responsible for the implementation of the project), decided to hold a national exposition (Expo.02) in the region of the three lakes of Neuchâtel, Biel and Murten in 2001 (Rieder et al. 2004). It subsequently requested a detailed feasibility study from the "Verein Landesausstellung” (hereafter Verein), which was responsible for the planning, construction and operation of Expo.02. This feasibility study concluded that it was possible to hold Expo.02 in the three-lakes region and that the financial contribution required from the federal state would amount to 170 million Swiss Francs (Rieder et al. 2004).

When it became clear, in the summer of 1999, that Expo.02 could not be carried out with an initial federal contribution of 130 million Swiss francs and that the project was on the brink of failure, thus threatening to embarrass the FC, the latter increased the federal contribution in a piecemeal manner. Leading up to the delayed realisation of Expo.02 in 2002, the parliament rubber-stamped a total of five additional financing requests from the FC. In the end, the total federal contribution amounted to 928 million Swiss Francs. These acts of approval were accompanied by an increasingly outraged parliament (National Council 1999). It blamed the FC for holding on to an exposition that was not worth the higher price and for presenting the parliament with an overmodest financing request while already covertly preparing the next one (Council of States 2001). Unsurprisingly, the FC repeatedly reassured the parliament that each new contribution was necessary due to unexpected developments and would be the last one.

\section{An inflated BCR}


Several reasons suggest that the FC endorsed the project based on overoptimistic assumptions. Even though the feasibility study submitted by the Verein mentions the private sponsorship potential of the exposition, an essential item in the feasibility study since private contributions would ultimately determine the financing deficit to be bridged by the FC, it did not consult potential sponsors (Swiss Federal Audit Office 2005, 39). Only five pages of the 1500 page feasibility study dealt with private sponsoring issues: in the final publication, this section was condensed into only two pages, without justifying the assumptions made. In general, the feasibility study can be seen as a mere pro forma document in whose quality the FC was not much interested. After all, the FC had already made its decision on the location before commissioning the feasibility study.

When approving the feasibility study, the FC not only confirmed the estimated federal contribution of 170 million Swiss Francs, but it reduced it even further to 130 million Swiss Francs. The FC’s clear choice of an overoptimistic forecast can be explained by the dilemma it found itself in when deciding about Expo.02. On one hand, there was a broad public and political majority that wanted the FC to endorse Expo.02. On the other hand, the FC faced a tight federal budget and general scepticism towards huge statist interventions (Rais and Ammann 2013). When justifying the 130 million Swiss francs, the FC clarified that there would not be any further contributions (NZZ 2005). In short, the federal contribution, which parliament approved in December 1996, was not based on a 'realistic' estimate but on overoptimistic calculations, which unavoidably would have to be corrected by the opening of Expo.02.

\section{The use of salami tactics}

Several motivations lead me to argue that the five additional contributions cannot solely be explained by unforeseeable developments and that the reproaches made by parliamentarians about the use of salami tactics are at least partially justified. As previously outlined, after the FC made the decision about the location and initial investments, it had to proceed with Expo.02, 
since terminating it would have been hugely embarrassing and would have resulted in high sunk costs. This must be borne in mind when considering that the FC refrained from conducting a comprehensive plausibility probe of all financing assumptions, even after a report published in September 1999 had made it clear that the estimates about future revenues and expenses were overoptimistic (Hayek-Engineering 1999). Among these, the estimate of contributions from private sponsors to the Expo was the most crucial. From 1996 until the actual date of the exposition, the FC consistently ignored expert advice and clung to utterly unrealistic third-party contribution forecasts (Swiss Federal Audit Office 2005, 90). According to the evaluation by the Control Committee of the Council of States (2001), the Swiss parliament's second chamber, from April 1999 on, the FC could have easily realised that its assumption was hugely overoptimistic. So, while there is no definitive proof that the FC actively disregarded information, it nevertheless acted according to the maxim, 'What I don't know, won't hurt me', sticking to the estimates of the Verein for as long as possible, despite ever more overwhelming proof of overoptimistic forecasts.

\section{The blame-reducing and blame-deflecting effects of salami tactics}

For the FC, this strategy paid off. The use of salami tactics allowed the FC to downplay the perceived loss by framing the whole project in positive terms such that, despite the need for further financing, it was still worth the (additional) price. Once, the FC explicitly labelled Expo.02 as a 'limited debacle', and it called the management problems that had caused the delays a 'salutary crisis' that finally allowed the FC to intervene and set things right (BAZ 1999). In an explanation to parliament, the FC framed an additional contribution as a 'positive sign' that allowed the Verein to continue with the project (Federal Council 1999). This framing strategy would obviously not have been credible, but rather downright brazen, had the FC gone over the books more thoroughly and requested a correspondingly larger sum as early as October 1999, when the framing contest intensified for the first time. The growing number of 'no votes' by parliamentarians for the various additional financing requests suggests that the application 
of salami tactics helped the FC to keep blame at a tolerable level until the debate surrounding the fifth financing request. While the first four financing requests received a maximum of 39 'no votes', the fifth financing request received 54 'no votes' and numerous abstentions (with 118 affirmative votes) (Swiss Federal Audit Office 2005, 26). This indicates that salami tactics helped the FC to avoid parliament's termination of Expo.02 - an outcome that would have redounded onto the FC as the politically responsible patron.

Second, salami tactics also helped the FC maintain the perception that the Verein was primarily responsible for the cost overruns. When justifying an additional contribution before parliament, the FC repeatedly deflected blame for cost overruns by accusing the Verein of badly managing Expo.02, thereby distracting from its responsibility for having accepted overoptimistic forecasts in the first place (BAZ 1999). The parliament long accepted the FC's assignment of responsibility and primarily blamed the Verein for the waste of public money (Rieder et al. 2004, 131). Only in spring 2002, on the occasion of the fifth financing request, did parliamentarians start to intensively blame the FC for hijacking parliament (Swiss Federal Audit Office 2005, 26-27). Overall, the use of salami tactics facilitated the reduction and deflection of blame during the framing contest about the perception of Expo.02.

\section{Project consequences}

The consequences of the use of salami tactics in the case of Expo.02 are mainly of a political nature. They allowed the FC to remove the parliament's control function during the implementation phase. Having accepted modest financing requests in the beginning, the parliament had to grudgingly accept further contributions, even after the total contributions had exceeded its reservation price. In the meantime, the FC was able to set things right, i.e. to correct for initial planning mistakes and, despite a one-year delay and significant extra costs, make the project a success that all parties - albeit tacitly - agreed had been worth paying the higher price for. 


\section{Discussion}

The preceding section provides a first empirical test of the expectations developed in the theory section by studying salami tactics in two very different cases. A comparison of the two cases provides a number of insights about salami tactics and their use during the implementation of large-scale public projects. First, the cases reveal that salami tactics are a versatile instrument in the tug-of-war over the public perception of a project, as they are applicable to both delays and cost overruns. While salami tactics in the BER case worked primarily on the time dimension, through the stepwise delay of the opening date, in the Expo.02 case, they worked on the cost dimension by gradually increasing the federal contribution. However, in both cases, salami tactics fulfilled the same purpose for the politicians overseeing project implementation. They made it possible to more credibly deflect responsibility for delays and cost increases and made the perceived loss appear more publicly tolerable for longer. Politicians used salami tactics to uphold the impression that the project was still on the road to success.

Second, despite their blame-reducing and blame-deflecting effects, the cases reveal that salami tactics are not a panacea for politicians in charge of projects based on overoptimistic forecasts. The longer the postponement of the opening date of the BER, the less effective salami tactics became, since the public, media and political opponents no longer accorded credibility to the mayor's assurances that the opening of the airport was within reach. Over time, official reports and investigative journalism produced ever more information about the severity of the underlying problems that rendered the mayor's justifications increasingly implausible. Also, in the case of Expo.02, it is evident that parliament experienced growing mistrust in the FC's assurances that a specific contribution would be the last. These observations suggest that salami tactics work less successfully when there is a substantial lapse in time and when there is more repetition in their use. The more repeated the application of salami tactics, the higher the likelihood that political opponents and the media will become suspicious and that, in-between the slicing, information about the real state of the project will become public and diminish the 
interpretive room to apply salami tactics. If official reports, investigative journalists, or whistleblowers, reveal severe problems that cannot be solved easily but persist over time, like the inoperable fire protection system in the BER case, salami tactics become particularly difficult to apply. When severe problems become public, politicians in charge must stop propagating optimism and must instead make major course corrections.

Third, the cases highlight the methodological difficulties encountered when assessing whether stepwise announcements are the result of salami tactics (the claim put forward in this article) or of unforeseen developments (the most plausible alternative explanation). Given the high complexity of large-scale projects, politicians can usually concoct a variety of reasons that justify their faith in a specific opening date or cost estimate, and the researcher must assess the substance of each of these alleged reasons. Moreover, as the Expo.02 case suggests, politicians can apply salami tactics in an attenuated form. This may be the case when a politician does not actively disregard information but knows quite well that considerable optimism still looms below the project surface and therefore refrains from making this an object of political discussion. Given these complications, it will often be difficult to provide evidence that strongly confirms the use of salami tactics. However, the analytical steps proposed above show potentially promising ways of combining pieces of evidence. Multiple pieces of evidence can add up to considerable affirmative evidence; evidence that decisively weakens the alternative explanation that politicians made step-wise announcements to the best of their knowledge (Collier 2011).

Finally, and most importantly, the cases reveal that salami tactics can be hugely consequential for the fate of large-scale public projects. In both cases, salami tactics prolonged the resolution of underlying problems. For example, the faulty fire protection system in the BER case or poor management within the Verein could have been tackled earlier had the politicians not jumped to announce that the projects, and their opening dates or costs, were still under control. By downplaying problems and risks, salami tactics help to uphold a favourable perception of a 
project during its implementation. In doing so, salami tactics facilitate a kind of 'groupthink' that a troubled project is really on track when, in reality, it is not ('t Hart 1994). Salami tactics allow project contractors and politicians to ward off critical questions from outsiders and delay neutral evaluations of a project's real state of implementation. The BER case further demonstrates that salami tactics, through their effect on acceleration measures and related planning mistakes, can become an independent driver of further cost overruns and delays. Consequently, salami tactics can lock a project in on a self-undermining path that cements, or even increases, the waste of public resources and potentially distorts their allocation to other projects (Cantarelli et al. 2010). These observations notwithstanding, I caution against an all too negative assessment of the consequences of salami tactics. The Expo.02 case suggests that salami tactics can enable politicians to pull through with a project that temporarily encounters difficulties but still develops into a widely perceived policy success. Whether salami tactics have negative or positive consequences primarily depends on the severity of the problems that they help to downplay and prevent from being addressed. If salami tactics prevent or delay the addressing of problems that are crucial for a project's successful implementation, like in the BER case, negative consequences will clearly prevail. In these situations, politicians endanger implementation success by applying salami tactics. On the contrary, if the (downplayed) problems are less severe, as in the Expo.02 case, salami tactics can also become a 'project protection measure' that saves projects from being killed by short-sighted and overblown criticism.

\section{Conclusion}

This article contributes to the understanding of the trajectory of large-scale public projects by conceptualising and describing an important blame management strategy used by politicians during the implementation of such projects: the stepwise announcement of delays and/or cost overruns intended to reduce and deflect the blame emerging for a project that turns out to be 
more expensive or takes longer to complete than initially communicated. Salami tactics can influence the fate of individual projects and the allocation of public resources. The study of salami tactics sheds light on two aspects of large-scale public projects that crucially add to our understanding of the implementation of such projects: the political framing contests that take place when a project's inflated BCR diminishes and the blame management strategies that politicians adopt during these framing contests.

As the first study that focuses on this hitherto neglected, but important and widely observed, blame management strategy, this article offers multiple starting points for future research. With regard to salami tactics, it is important to refine our knowledge about their applicability and their consequences. This article suggests that salami tactics, while applicable to both cost increases and delays, become implausible under certain conditions. If politicians apply them over a long time span, political opponents and the media tend to become suspicious, as more information about the real state of a project becomes public. This deprives politicians of the possibility to continue to frame a project in a positive way. With regard to consequences, salami tactics' influence on cost development and completion times are likely to be especially negative if their application helps to cover up severe underlying problems that stand in the way of the successful implementation of the project. As these suggestions are based on the analysis and comparison of two cases, they must be validated in future empirical work.

More generally, this article demonstrates the theoretical potential of the literature on policy failure and blame management for elucidating the politics surrounding the implementation of large-scale public projects. This literature allows to conceptualise the often bumpy implementation of large-scale public projects as political framing contests about the dominant public perception of these projects. Moreover, the article demonstrates that these framing contests can influence the trajectories of such projects. To obtain a more detailed understanding of these framing contests and their implications for the fate of policy projects, future research should explore the use of other blame management strategies (Hinterleitner 2018; Hood 2011; 
Mortensen 2016; Boin et al. 2010) during the implementation of these projects. A concrete example of the latter is the creation of so called 'fuzzy' governance structures (Bache et al. 2015), which are often found in the organisation of complex projects and which are sometimes said to facilitate the diffusion and deflection of blame. Overall, there is a strong case to be made for analysing the trajectory of large-scale public projects from a blame management perspective. 


\section{About the author}

Markus Hinterleitner is a postdoctoral researcher at the KPM Center for Public Management of the University of Bern.

\section{Address for correspondence}

Dr. Markus Hinterleitner

University of Bern

KPM Center for Public Management

Schanzeneckstrasse 1

P.O. Box

CH-3001 Bern

Switzerland

markus.hinterleitner@kpm.unibe.ch

\section{Acknowledgements}

I want to thank Tobias Arnold, Karin Ingold, David Kaufmann, Doina Radulescu, Fritz Sager, Eva Thomann, the three anonymous referees, and the editors for insightful suggestions and comments. 


\section{References}

Bache, I., Bartle, I., Flinders, M. and Marsden, G. (2015) ‘Blame Games and Climate Change: Accountability, Multi-Level Governance and Carbon Management', The British Journal of Politics \& International Relations 17(1):64-88.

BAZ (1999) ‘Der Streit um die Expo eskaliert’, October 07:1.

$\begin{array}{llllll}\text { Berlin } & \text { Regional } & \text { Court. } & \text { 2014. } & \text { Ruling } & \end{array}$ http://www.tagesspiegel.de/downloads/11057368/1/berurteil.pdf.

BHoR (2012a) Plenarprotokoll 17/13: May 10, 2012.

BHoR (2012b) Ausschuss für Bauen, Wohnen und Verkehr: May 18, 2012.

BHoR (2012c) Plenarprotokoll 17/16: August 30, 2012.

BHoR (2012d) Plenarprotokoll 17/17: September 13, 2012.

BHoR (2012e) Plenarprotokoll 17/19: October 25, 2012.

BHoR (2013) Plenarprotokoll 17/23: January 10, 2013.

Birkland, T. A. (1998) ‘Focusing Events, Mobilization, and Agenda Setting’, Journal of Public Policy 18(01):53-74.

Boin, A., Hart, J., McConnell, A. and Preston, T. (2010) 'Leadership Style, Crisis Response and Blame Management: The Case of Hurricane Katrina', Public Administration 88(3):706-723.

Boin, A., 't Hart, P. and McConnell, A. (2009) 'Crisis exploitation: political and policy impacts of framing contests', Journal of European Public Policy 16(1):81-106.

Bovens, M. and 't Hart, P. (2016) 'Revisiting the study of policy failures', Journal of European Public Policy 23(5):653-666.

Bovens, M. and ‘t Hart, P. (19969 Understanding policy fiascoes. Transaction Publishers, New Brunswick [N.J.].

Cantarelli, C. C., Flyvbjerg, B., van Wee, B. and Molin, E. J. E. (2010) 'Lock-in and its influence on the project performance of large-scale transportation infrastructure projects: 
investigating the way in which lock-in can emerge and affect cost overruns', Environment and Planning B: Planning and Design 37(5):792-807.

Collier, D. (2011) 'Understanding Process Tracing', PS: Political Science \& Politics 44(04):823-830.

Control Committee Council of States (2001) Probleme bei der Vorbereitung und Organisation der Landesausstellung 2001 (Expo.01). Eine Aufarbeitung im Rahmen der parlamentarischen Oberaufsicht.

Council of States (2001) ‘01.011 Voranschlag 2001. Nachtrag I (Umwandlung von 300 Mio.

Fr. an Defizitgarantie für die Expo.02 in ein Darlehen)', Amtliches Bulletin Ständerat 3. Sitzung, Sommersession 2011.

Federal Council (1999) 'Botschaft über einen Zusatzkredit für die Landesausstellung vom 8. Oktober 1999’, Bundesblatt 47.

Flyvbjerg, B., Bruzelius, N. and Rothengatter, W. (2003) Megaprojects and risk: An anatomy of ambition. Cambridge University Press, Cambridge.

Flyvbjerg, B., Holm, M. S. and Buhl, S. (2002) 'Underestimating Costs in Public Works Projects: Error or Lie?', Journal of the American Planning Association 68(3):279-295.

Fülling, T. (2014) 'Ex-Technikchef Weyer kritisiert Eingriffe der Politik am BER', Berliner Morgenpost, October 10.

George, A. L. and Bennett, A. (2005) Case studies and theory development in the social sciences. MIT Press, Cambridge, Mass.

Hayek-Engineering (1999) Bericht über die Standortbestimmung der Expo.01. Im Auftrag des Strategischen Ausschusses, Biel.

Hinterleitner, M. (2017) ‘Reconciling Perspectives on Blame Avoidance Behaviour’, Political Studies Review 15(2):243-254.

Hinterleitner, M. (2018) 'Policy failures, blame games and changes to policy practice’, Journal of Public Policy 38(2):221-242. 
Hinterleitner, M. and Sager, F. (2017) ‘Anticipatory and reactive forms of blame avoidance: Of foxes and lions', European Political Science Review 9(4):587-606.

Hinterleitner, M. and Sager, F. (2018) 'Blame, reputation and organizational responses to a politicized climate', in: Bach, T. \& Wegrich, K. (eds.) The blind spots of public bureaucracy and the politics of non-coordination. Palgrave Macmillan, London, 133-150.

Hoffmann, C. (2012) 'Es brennt: Berliner Großflughafen’, Frankfurter Allgemeine Zeitung, July 07.

Hood, C. (2011) The blame game: Spin, bureaucracy, and self-preservation in government. Princeton University Press, Princeton.

Hood, C., Jennings, W., Dixon, R., Hogwood, B. and Beeston, C. (2009) 'Testing times: Exploring staged responses and the impact of blame management strategies in two examination fiasco cases’, European Journal of Political Research 48(6):695-722.

Jennings, W. (2012) 'Why costs overrun: Risk, optimism and uncertainty in budgeting for the London 2012 Olympic Games’, Construction Management and Economics 30(6):455-462. Kurpjuweit, K. and Tretbar, C. (2014) 'Ein Protokoll des Scheiterns: Brandbrief an den BERAufsichtsrat', Der Tagesspiegel, April 06.

Lovallo, D. and Kahneman, D. (2003) 'Delusions of success', Harvard business review 81(7):56-63.

McConnell, A. (2010) Understanding policy success: Rethinking public policy. Palgrave Macmillan, New York.

McConnell, A. (2011) 'Success? Failure? Something in-between? A framework for evaluating crisis management', Policy and Society 30(2):63-76.

McConnell, A. (2017) 'Hidden agendas: Shining a light on the dark side of public policy', Journal of European Public Policy:1-20.

Mortensen, P. B. (2016) 'Agencification and Blame Shifting: Evaluating a Neglected Side of Public Sector Reforms', Public Administration 94(3):630-646. 
National Council (1999) '99.081 Expo.02 Zusatzkredit’, Amtliches Bulletin Nationalrat 2. Sitzung, Wintersession 1999.

NZZ (2005) Lehrstück für die Bundespolitik: Die Expo 1⁄2 zwischen Chaos und Verwirklichung, October 06:15.

Pal, L. A. and Weaver, R. K. (2003) The government taketh away: The politics of pain in the United States and Canada. Georgetown University Press, Washington, D.C.

Rais, G. and Ammann, Y. (2013) Überlegungen zur konjunkturellen und strukturellen Entwicklung der Schweizer Wirtschaft, Neuchâtel.

Rieder, S., Lehmann, L. and Ledermann, S. et al. (2004) Analyse der Projektorganisation und Projektsteuerung der Expo.01/02: Bericht zuhanden der Eidgenössischen Finanzkontrolle EFK, Lucerne.

Sanderson, J. (2012) 'Risk, uncertainty and governance in megaprojects: A critical discussion of alternative explanations’, International Journal of Project Management 30(4):432-443.

Swiss Federal Audit Office (2005) Expo.01/02: Auftrag mit unbeschränkter Haftung: Sonderuntersuchung zur Landesausstellung im Drei-Seen-Land.

't Hart, P. (1994) Groupthink in government: A study of small groups and policy failure, Paperback ed. Johns Hopkins University Press, Baltimore, Md.

van Marrewijk, A., Clegg, S. R., Pitsis, T. S. and Veenswijk, M. (2008) 'Managing publicprivate megaprojects: Paradoxes, complexity, and project design’, International Journal of Project Management 26(6):591-600.

Weaver, R. K. (1986) ‘The Politics of Blame Avoidance’, Journal of Public Policy 6(4):371398.

Weaver, R. K. (2014) ‘Compliance Regimes and Barriers to Behavioral Change’, Governance 27(2):243-265. 


\section{Online Appendix}

Table A1. Case selection criteria and their purposes

\begin{tabular}{|c|c|c|}
\hline Purpose of the empirical analysis & $\begin{array}{l}\text { Case selection criterion fulfilling } \\
\text { the purpose }\end{array}$ & Reasoning \\
\hline $\begin{array}{l}\text { Explore the use of salami tactics } \\
\text { and test their blame-reducing and } \\
\text { blame-deflecting effects }\end{array}$ & $\begin{array}{l}\text { Select two cases with projects based } \\
\text { on overoptimistic BCRs }\end{array}$ & $\begin{array}{l}\text { Salami tactics need to be explored in } \\
\text { cases where they can theoretically occur. } \\
\text { Overoptimistic projects that attract blame } \\
\text { during implementation are a precondition } \\
\text { for the use of salami tactics }\end{array}$ \\
\hline $\begin{array}{l}\text { Create further insights on the shape, } \\
\text { applicability, and consequences of } \\
\text { salami tactics }\end{array}$ & Select two 'most different' cases & $\begin{array}{l}\text { Differences can be leveraged to create } \\
\text { additional insights on the factors that } \\
\text { influence the shape, applicability, and } \\
\text { consequences of salami tactics }\end{array}$ \\
\hline $\begin{array}{l}\text { Create as much representativeness } \\
\text { as possible }\end{array}$ & Select two 'most different' cases & $\begin{array}{l}\text { Evidence for the use of salami tactics in } \\
\text { two very different cases increases the } \\
\text { likelihood that they occur during the } \\
\text { implementation of a wide range of } \\
\text { overoptimistic projects }\end{array}$ \\
\hline
\end{tabular}


Table A2. Main data and their primary uses

\begin{tabular}{|c|c|c|c|}
\hline & "Main data analysed for BER case & "Main data analysed for Expo.02 case & Primary use \\
\hline $\begin{array}{l}\text { Parliamentary } \\
\text { debates }\end{array}$ & $\begin{array}{l}\text { Transcripts of debates in the Berlin } \\
\text { House of Representatives on } 3 \text { June } \\
\text { 2010, } 10 \text { May 2012, } 18 \text { May } 2012 \\
\text { (in the Committee on Building, } \\
\text { Housing, and Transport), } 24 \text { May } \\
\text { 2012, } 30 \text { August 2012, } 25 \text { October } \\
\text { 2012, } 10 \text { January 2013, } 16 \text { January } \\
\text { 2014 and } 8 \text { May 2014 }\end{array}$ & $\begin{array}{l}\text { Transcripts of debates in the National } \\
\text { Council (first chamber) on } 7 \\
\text { December 1999, } 16 \text { June 2000, } 27 \\
\text { September } 2001 \text { and } 6 \text { March 2002; } \\
\text { transcripts of debates in the Council of } \\
\text { States (second chamber) on } 16 \\
\text { December 1999, } 6 \text { June } 2000 \text { and } 14 \\
\text { March 2002; written statements by the } \\
\text { FC towards parliament from } 8 \text { October } \\
1999 \text { and } 30 \text { January } 2002\end{array}$ & $\begin{array}{l}\text { Assessment of } \\
\text { step-wise } \\
\text { announcements } \\
\text { and their } \\
\text { justification, } \\
\text { assessment of } \\
\text { reactions of } \\
\text { political opponents }\end{array}$ \\
\hline Media coverage & $\begin{array}{l}60 \text { articles in 'Die Welt' (a leading } \\
\text { quality paper) and } 90 \text { articles in } \\
\text { 'B.Z.' (a local paper) between June } \\
2010 \text { and February } 2014\end{array}$ & $\begin{array}{l}54 \text { articles in 'NZZ' (a leading quality } \\
\text { paper) and } 21 \text { articles in } \\
\text { 'TagesAnzeiger' (a local paper) } \\
\text { between March } 1999 \text { and May } 2002\end{array}$ & $\begin{array}{l}\text { Assessment of } \\
\text { step-wise } \\
\text { announcements } \\
\text { and their } \\
\text { justification, } \\
\text { assessment of } \\
\text { reactions by } \\
\text { political opponents }\end{array}$ \\
\hline $\begin{array}{l}\text { Official and } \\
\text { expert reports }\end{array}$ & $\begin{array}{l}\text { Berlin Regional Court, 2014, ruling } \\
93 \text { O 55/13; Ernest and Young, } \\
\text { 2012, Sachverhaltsdarstellung zu } \\
\text { Störungen des Projektablaufes und } \\
\text { deren Auswirkungen }\end{array}$ & $\begin{array}{l}\text { Swiss Federal Audit Office, 2005, } \\
\text { Expo.01/02: Auftrag mit } \\
\text { unbeschränkter Haftung: } \\
\text { Sonderuntersuchung zur } \\
\text { Landesausstellung im Drei-Seen-Land; } \\
\text { Rieder, S., et al., 2004, Analyse der } \\
\text { Projektorganisation und } \\
\text { Projektsteuerung der Expo.01/02: } \\
\text { Bericht zuhanden der Eidgenössischen } \\
\text { Finanzkontrolle EFK; Control } \\
\text { Committee Council of States, 2001, } \\
\text { Probleme bei der Vorbereitung und } \\
\text { Organisation der Landesausstellung } \\
\text { 2001 (Expo.01). Eine Aufarbeitung im } \\
\text { Rahmen der parlamentarischen } \\
\text { Oberaufsicht }\end{array}$ & $\begin{array}{l}\text { Gauge of level of } \\
\text { information } \\
\text { politicians possess } \\
\text { when announcing } \\
\text { cost } \\
\text { overruns/delays }\end{array}$ \\
\hline
\end{tabular}

Note: I retrieved relevant articles from the abovementioned newspapers via the Factiva database using several case-specific keywords. Moreover, I occasionally consulted (and cite in the text) articles from other outlets in case they could provide further insights into the cases (e.g. pieces of investigative journalism). All other documents are available from the author upon request. 